\title{
Aikuiskasvatuksen opiskelijoiden opiskelukokemuksista ja urakehityksestä
}

\begin{abstract}
Peltokoski, Jukka. 1985. Aikuiskasvatuksen opiskelijoiden opiskelukokemuksista ja urakehityksestä. Aikuiskasvatus 5, 1, 11-14. - Artikkeli perustuu kirjoittajan pro gradu -tutkielmaan, jossa tutkittiin Tampereen yliopistossa vuosina 1970-81 opiskelleiden aikuiskasvatuksen laudaturin suorittaneiden yhteiskuntatieteiden ja filosofian kandidaattien sosiaalista taustaa, opiskeluun liittyviä seikkoja, työhönsijoittumista sekä työuran kehittymistä. Tutkimuksen keskeisenä tarkoituksena oli tuottaa tietoa aikuiskasvatuksen opetuksen edelleen kehittämiseksi. Yleisesti tarkastellen opiskelijat olivat suhteellisen tyytyväisiä aikuiskasvatuksen opetukseen, he olivat sijoittuneet hyvin ammattiurallaan. Keskeisimpinä puutteina koettiin se, että opetuksessa ei vastaajien mielestä painotettu tarpeeksi didaktiikkaa, opetuksen suunnittelua ja yleensä käytännön aikuiskasvatustyössä tarvittavia tietoja ja taitoja.
\end{abstract}

\section{Tutkimuksen tarkoitus ja kohdejoukko}

Tutkimuksen tarkoituksena oli tuottaa tietoa aikuiskasvatuksen kehittämiseksi yliopistollisena oppiaineena. Koulutuksen kehittämistä on käsitelty ensisijaisesti ammatillisen tehtävän tai ulottuvuuden näkökulmasta. Lähtökohtana oli ns. ammattikuva-ajattelu, jonka mukaan koulutuksen sisällöt tulisi suunnata ao. alan keskeisimpien työammattien ja niiden keskeisimpien työtehtävien mukaan.

Tutkimuksen peruskohdejoukon muodostivat kaikki Tampereen yliopistossa vuosina 1970-81 ylemmän kandidaattitutkinnon suorittaneet henkilöt, joilla oli aikuiskasvatus pää- tai sivulaudaturaineena sekä aikuiskasvatuksen laudaturin ylimääräisenä opiskelijana suorittaneet henkilöt $(\mathrm{N}=139)$. Tutkimusjoukkoon hyväksytyistä 139:stä henkilöstä $40 \%$ oli miehiä ja $60 \%$ naisia. Tutkimus oli luonteeltaan empiirinen ja aineiston kerääminen tapahtui postikyselyn avulla. Hyväksyttäviä vastauksia tuli 119 joten palautusprosentti oli 86. Kyselyyn vastanneista henkilöistä $37 \%$ oli miehiä ja $63 \%$ naisia. Pääaineena aikuiskasvatuksen laudaturin suorittaneita oli $83 \%$ ja sivulaudaturin suorittaneita $17 \%$.

\section{Pääaineen valintaan vaikuttaneet tekijät ja sivuaineiden valinta}

Tutkimuksessa kävi ilmi, että aikuiskasvatuksen pääaineekseen valinneilla opiskelijoilla ehdottomasti merkittävimpänä tekijänä oli henkilökohtainen kiinnostus ainetta kohtaan. Seuraaviksi eniten aineen valintaan vaikuttivat: tarkoituksenmukaisuus työhönsijoittumista ajatellen, aineen opiskelu kehittää persoonallisuutta, aine liittyy läheisesti johonkin tiettyyn ammattiin, se antaa tärkeää tietoa yhteiskunnasta sekä tieteellinen kiinnostus aineeseen ja alan tutkimukseen. Tosin suhteellisen monen kohdalla pääaineen valinta oli ollut melko sattumanvaraista.

Kokonaisuudessaan aikuiskasvatuksen pääaineopiskelijoiden pääaineen valintaan vaikuttaneissa intresseissä yhtyvät toisaalta tietyt ammatilliset ja itsensäkehittämiseen liittyvät motiivit henkilökohtaiseen kiinnostukseen alaa ja sen kehittämistä kohtaan. Sen sijaan oppiaineen valinnassa ei korostunut opiskelun suorittamiseen liittyvät ulkokohtaiset tekijät, kuten opintojen suorittamisen helppous tai opintojen nopea suorittaminen. Opintojen alkuvaiheessa keskeisen opiskelumotiivin muodosti käsitys aikuiskasvatuksen sisällöllisestä relevanttiudesta sekä oman persoonallisuuden kehittymisen että ammatillisen toiminnan kannalta.

Sivuaineekseen pääaineopiskelijat olivat valinneet enimmäkseen jonkin yhteiskuntatieteellisen oppiaineen $(71 \%$ ), mutta myös taloudellis-hallinnollisten aineiden osuus oli suhteellisen suuri $(20 \%)$. Ylivoimaisesti suosituin sivuaine oli sosiaalipolitiikka, toiseksi suosituin sosiologia ja kolmansina olivat psykologia ja julkishallinto. Koko tutkimusjoukon aineyhdistelmistä löytyi kaikkiaan 38 eri sivuainetta. 


\section{Opiskelun kesto}

Opiskeluajan mediaani aikuiskasvatuksen pääaineekseen valinneilla henkilöillä, jotka olivat tulleet suoraan tiedekuntaan, oli 5.7 vuotta ja opetusjaostoista siirtyneillä 7.3 vuotta.

Keskeisimmät valmistumista viivästyttäneet syyt olivat ansiotyössä käynti ja taloudelliset vaikeudet ( $33 \%$ ), vaikeudet opiskelussa (etenkin pro-gradu-tutkielman tekemisen vaikeus; opettajien taholta tuleva ohjaus oli usein koettu puutteelliseksi) ja motivaatio-ongelmat (16\%).

Opintojen viivästymistä selittää se, että lukukausien aikana lähes $75 \%$ oli ollut töissä ainakin silloin tällöin; $27 \%$ lähes jatkuvasti kokopäivätoimessa. Ongelmana koettiin se, että opiskeluaikainen työ vastasi opiskelualaa suhteellisen heikosti.

\section{Työhön sijoittuminen}

Pääaineopiskelijoista $68 \%$ oli saanut työtä heti valmistumisensa jälkeen tai he olivat työssä jo valmistumishetkellä. Vastaava prosenttiluku sivuaineopiskelijoilla oli 90. Kuusi kuukautta valmistumisen jälkeen pääaineopiskelijoista oli sijoittunut työelämään jo $94 \%$. Tältä osin työelämään sijoittumista on pidettävä suhteellisen hyvänä.

Tarkasteltaessa aikuiskasvatuksen pääaineopiskelijoiden työsuhteen vakinaisuutta, havaittiin että valmistumisen jälkeen ensimmäinen työpaikka oli ollut $36 \%$ :lla vakinainen virka tai toimi, $20 \%$ :lla viran tai toimen sijaisuus, $24 \%$ :lla määräaikainen ja $15 \%$ :lla tilapäinen työsuhde.

Ensimmäinen työnantaja oli tavallisimmin ollut kunta tai kuntainliitto, joskin valtion palvelukseen oli sijoituttu lähes yhtä usein (37\% ja $31 \%$ ). Pääaineopiskelijoista $20 \%$ oli sijoittunut aluksi jonkin järjestön, säätiön tai yhdistyksen palvelukseen ja vain n. $8 \%$ oli sijoittunut erilaisiin yrityksiin.

Pääaineopiskelijoista oli $42 \%$ sijoittunut opetusalalle, noin joka neljäs sosiaali- ja terveydenhuoltoalalle ja joka kymmenes hallinnolliselle alalle.

Vain noin kolmasosalla ensimmäinen toimi oli ollut koulutusta vastaava, yli puolella se oli ollut osittain koulutusta vastaava ja noin $16 \%$ :lla täysin koulutusta vastaamaton.

Mitä paremmin oli menestytty opiskelussa, sitä paremmin oli myös sijoituttu koulutusta vastaavaan toimeen. Valmistumisvuoden mukaan myöhemmin valmistuneet olivat sijoittuneet useammin koulutusta vastaaviin tehtä- viin. Kun $1970-73$ valmistuneista $23 \%$ oli päässyt täysin koulutusta vastaaviin tehtäviin niin vastaava luku 1974-77 valmistuneiden kohdalla oli $36 \%$ ja 1978-81 valmistuneilla $44 \%$.

Naiset olivat sijoittuneet hieman miehiä heikommin koulutusta vastaaviin toimiin. Jos henkilöllä oli ollut jokin aikaisemmin suoritettu ammatillinen tutkinto, niin sitä paremmin hän oli sijoittunut täysin koulutusta vastaaviin tehtäviin heti ensimmäisessä työpaikassaan. Sivuaineena aikuiskasvatuksen laudaturin suorittaneet olivat sijoittuneet hieman pääaineopiskelijoita paremmin koulutustaan vastaaviin tehtäviin.

Eräs mielenkiintoinen seikka ajatellen ammatillista sijoittumista on tietysti toimiminen aikuiskasvatusalalla. Tutkimuksesta ilmeni, että kaikista vastanneista $39 \%$ ei ollut missään vaiheessa toiminut aikuiskasvatusalalla. Pääaineopiskelijoista tällaisia henkilöitä oli n. $40 \%$ ja sivulaudaturin suorittaneista $35 \%$.

Kun tarkastellaan aikuiskasvatuksen alueella toimineiden henkilöiden ensimmäisen toimen luonnetta, niin havaitaan, että noin puolella $(\mathrm{N}=72)$ se oli ollut päätoiminen hallinto-, suunnittelu- ja/tai organisointitehtävä, ja noin joka neljännellä päätoiminen opetustehtävä.

Suurimpana yksittäisenä aikuiskasvatuksen opiskelijoita rekrytoivana organisaationa olivat olleet kansalais- ja työväenopistot, jotka olivat olleet noin joka neljännen opiskelijan ensimmäinen alan työpaikka. Kokonaisuudessaan tutkittujen henkilöiden ammattiin sijoittuminen oli ollut varsin laaja-alaista ja se käsitti muodossa tai toisessa kaikki aikuiskasvatuksen alat.

Naisten ja miesten välillä oli eroja siten, että naisilla oli useammin ensimmäisenä aikuiskasvatusalan toimena ollut jokin tehtävä kansanopistoissa, opintokeskuksissa tai ammatillisissa kurssikeskuksissa. Miehet puolestaan olivat rektytoituneet useammin kansalais- ja työväenopistoihin, henkilöstökoulutukseen tai muun ammatillisen aikuiskoulutuksen piiriin.

\section{Toimet tutkimushetkellä}

Kyselyhetkellä 1982 työskenteli aikuiskasvatusalalla $45 \%$ kyselyyn vastanneista henkilöistä. Päätoimisia oli koko joukosta $42 \%$. Päätoimisissa aikuiskasvatustehtävissä oli miehistä $50 \%$ ja naisista $37 \%$.

Enemmistö entisistä aikuiskasvatuksen opiskelijoista toimi siis muualla kuin aikuiskasvatusalalla. Heistä suurin yksittäinen ryhmä (35\%) toimi sosiaali- ja terveydenhuoltoalalla ja toiseksi suurin ryhmä ( $15 \%)$ eri alojen tut- 
kimus- ja suunnittelutehtävissä. Vajaa $13 \%$ toimi kirjasto- ja museoalalla samoin kuin tiedotus- ja graafisen alan työtehtävissä. Noin $8 \%$ aikuiskasvatusalan ulkopuolelle sijoittuneista oli kuntien koululaitosten tai keskiasteen ammatillisten oppilaitosten palveluksessa ja loput useilla eri aloilla lähinnä johtavissa tehtävissä.

Kaikista tutkimukseen osallistuneista henkilöistä noin $74 \%$ :lla oli kyselyhetkellä vakinainen virka tai toimi. Viran tai toimen sijaisuuksia hoiti $5 \%$, määräaikaisessa työsuhteessa oli $9 \%$ ja tilapäisessä työsuhteessa $5 \%$ vastaajista.

Keskimääräinen toimiaika ensimmäisessä valmistumisen jälkeisessä toimessa oli ollut noin kaksi vuotta. Toimen tai työpaikan vaihdon syistä keskeisin oli se, että aikaisempi toimi oli ollut määräaikainen tai sijaisuus $(45 \%)$. Toiseksi keskeisin vaihdon syy oli ollut halu siirtyä kehittävämpiin, vaativampiin ja koulutusta paremmin vastaaviin tehtäviin $(29 \%)$. Muut syyt liittyivät joko perheeseen, työolosuhteisiin, vakinaiseen tai kokopäivätyöhön siirtymiseen ja aikaisemman työn huonoon palkkaukseen.

Työpaikan vaihtamisen yhteydessä oli tapahtunut selvää ammattiaseman nousua. $\mathrm{Ky}-$ selyhetkellä pääaineopiskelijoista oli kuntain/ kuntainliittojen palveluksessa lähes $50 \%$, valtion palveluksessa n. $20 \%$, järjestöjen, säätiöiden ja yhdistysten palveluksessa $18 \%$ ja yritysten palveluksessa $7 \%$.

Kyselyhetkellä vajaa puolet vastaajista oli mielestään täysin koulutusta vastaavissa tehtävissä, noin joka kolmannen tehtävät vastasivat osittain koulutusta ja vain vajaalla $7 \%$ :lla oli täysin koulutusta vastaamaton toimi. Tätä tulosta on pidettävä tyydyttävänä.

Työtyytyväisyys aikuiskasvatusta opiskelleilla oli suhteellisen hyvä. Tyytyväisimpiä vastaajat olivat työtehtävien monipuolisuuteen, mahdollisuuksiin toimia itsenäisesti, mahdollisuuteen kantaa vastuuta ja työsuhteen pysyvyyteen. Tyytymättömimpiä oltiin taas työhön rohdistuvaan arvonantoon, lomien määrään, kokonaistyömäärään ja ylenemismahdollisuuksiin. Erityisesti aikuiskasvatuksen alueella toimineet arvostivat työn monipuolisuutta, mahdollisuutta toimia itsenäisesti, työstä saatua omanarvontuntoa, mahdollisuutta kantaa vastuuta, työsuhteen pysyvyyttä ja mahdollisuuksia itsensä kehittämiseen. Eri vuosina valmistuneiden työtyytyväisyydessä ei ollut juurikaan eroja.

\section{Työn vaatimukset ja koulutuksen antamat valmiudet}

Selvityksessä verrattiin tehtäväryhmittäin työssä tarvittavia keskeisiä tiedonalueita ja taitoja sekä koulutuksen antamia valmiuksia. Kokonaisuudessaan aikuiskasvatusalalla toimivien tieto- ja taitoalueet ovat suhteellisen laaja-alaiset ja monipuoliset. Hallinto- ja suunnittelutehtävissä toimineet henkilöt arvioivat keskeisimmiksi tieto- ja taitoalueiksi omassa työssään opetuksen suunnittelun, neuvottelu- ja kokoustekniikan, koulutussuunnittelun, johtamistaidon sekä opetusmenetelmien hallinnan.

Tämän ryhmän mielestä koulutus oli antanut parhaiten valmiuksia koulutuspolitiikan, opetuksen suunnittelun, tutkimusaineiston keruun, opetusmenetelmien ja koulutussuunnittelun hallinnan osalta. Ao. ryhmä piti koulutuksen antamia valmiuksia riittämättöminä, vaikkakin sisällöllisten painotusten kannalta oikeansuuntaisina. Riittämättömimpinä koulutuksen antamat valmiudet koettiin opetusmateriaalin suunnittelun, johtamistaidon sekä neuvottelu- ja kokoustekniikan osalta.

Opetustehtävissä toimineet katsoivat puolestaan omalta kannaltaan keskeisimmiksi tietoja taitoalueiksi opetusmenetelmien, opetusmateriaalin suunnittelun, neuvottelu- ja kokoustekniikan, opetuksen suunnittelun ja opiskelutekniikan osa-alueet. Parhaiten koulutuksessa oli saatu valmiuksia opiskelutekniikan, tieteellisen tutkimuksen tekemisen, koulutuspolitiikan, tutkimusaineiston keruun sekä monitieteisen ja ongelmakeskeisen lähestymistavan vaativien työtehtävien hallintaan. Riittämättömimpänä pidettiin opetusmateriaalin suunnitteluun, johtamistaitoon, neuvottelu- ja kokoustekniikkaan sekä taloudenhoitoon liittyviä valmiuksia.

Ammatillisia ja muita tietoja ja taitoja voidaan ylläpitää ja hankkia myös valmistumisen jälkeisellä jatko- ja täydennyskoulutuksella. Aikuiskasvatusta opiskelleiden osallistuminen valmistumisen jälkeiseen lisäkoulutukseen on ollut hyvin epätasaista. Noin kolmasosa vastaajista ei ollut osallistunut lainkaan lisäkoulutukseen, osa oli ollut erilaisissa koulutustilaisuuksissa kymmeniä kertoja.

Koettu lisäkoulutustarve suuntautui ennen muuta kasvatustieteen, aikuiskasvatuksen ja psykologian alueille, didaktiikkaan, johtamiskoulutukseen jne. 
Edellä kuvattua työtehtävien vaatimusten ja koulutuksessa annettujen valmiuksien ristiriitaa voidaan pitää odotettuna, koska yliopistollisella peruskoulutuksella ei pystytä nykyisinkään kohtuulliseksi katsotun opiskeluajan (4-5,5 vuotta) ja tutkintovaatimusten puitteissa antamaan kaikkia niitä kvalifikaatioita, joita työelämässä tarvitaan. Tarkasteltaessa laajemmin aikuiskasvatuksen opetuksen ja opiskelun sisältöalueiden painottumista havaittiin joitakin selviä eroja eri vuosina valmistuneiden henkilöiden mielipiteissä. Koulutuksessa ollaan jossain määrin siirrytty filosofisten, historiallisten ja kulttuuripoliittisten kysymysten pohdiskelusta lähemmäs käytännön koulutus- ja kasvatustyötä, mutta vastaajien mielestä ei vielä riittävästi. Opiskelijoiden mielestä ne sisältöalueet, joita tulisi opetuksessa käsitellä laajemmin ovat: didaktiikka, käytännön aikuiskasvatustyö, viestintätaidot sekä opintojen ohjaus ja opiskelutekniikka.

Opiskelu- ja opetusmuotojen tehokkuutta arvioitaessa tehokkaimpina opetusmuotoina vuonna 1978 ja sen jälkeen valmistuneet henkilöt pitivät erilaisia harjoituskursseja ja -töitä (pro gradu-työn tekeminen, harjoituskurssit ja -työt, muut kirjalliset työt) sekä kirjatentteihin valmistumista. Luento-opetus koettiin selvästi heikoimpana opetusmenetelmänä.

Kun kysyttiin valitsisiko henkilö aikuiskasvatuksen pääaineeksi, jos hän voisi aloittaa opintonsa alusta, niin $57 \%$ pääaineopiskeli- joista vastasi kysymykseen myöntävästi ja $38 \%$ kieltävästi. Sen sijaan uudessa valintatilanteessa ei otettaisi enää niin usein sivuaineiksi esim. sosiaalipolitiikkaa tai sosiologiaa, vaan enemmän taloudellis-hallinnollisia (julkishallinto, tilastotiede, ATK) sekä humanistisia tieteitä (lähinnä kielet). Mainittakoon että uudelleen aikuiskasvatuksen pääaineekseen valitsevien suhteellinen osuus on suurempi kuin keskimäärin yhteiskuntatieteissä, humanistisissa tieteissä ja kasvatustieteissä ${ }^{1}$.

\section{Lopuksi}

Kokonaisuutena tarkastellen tutkimustulosten perusteella saa suhteellisen positiivisen käsityksen aikuiskasvatusta opiskelleiden työelämään sijoittumista ja uralla etenemisestä mutta vain osittain aikuiskasvatuksesta oppiaineena. Keskeisimpinä puutteina aikuiskasvatuksen opetuksessa koettiin se, että siinä ei painotettu tarpeeksi didaktiikkaan ja oppimateriaalin suunnitteluun liittyviä asioita, eikä yleisiin kommunikatiivisiin valmiuksiin ja johtamistaitoon liittyviä osa-alueita. Kuitenkin tuloksista kävi ilmi, että koulutuksessa oli vastaajien mielestä siirrytty jonkin verran lähemmäs käytännön koulutus- ja kasvatustyötä.

\footnotetext{
1 Ks. Jussila 1979. Jyväskylän yliopistosta vuosina 1970-75 kasvatustiede pääaineena valmistuneiden kasvatustieteiden kandidaattien työelämään sijoittuminen, Jyväskylän yliopisto. Kasvatustieteen laitos N:o 79, s. 58-59.
} 